\title{
Status and Constrain for Mechanization of Rice Harvesting System in Bangladesh
}

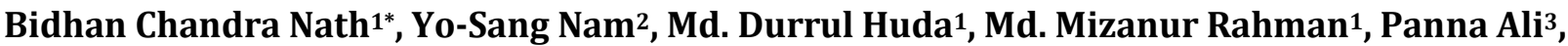 \\ Subrata Paul1
}

${ }^{1}$ Farm Machinery and Postharvest Technology Division, Bangladesh Rice Research Institute, Gazipur, Bangladesh

${ }^{2}$ TYM R\&D Center, Gongju, South Korea

${ }^{3}$ Entomology Division, Bangladesh Rice Research Institute, Gazipur, Bangladesh

Email: *bidhanbrri@gmail.com

How to cite this paper: Nath, B.C., Nam, Y.-S., Huda, Md.D., Rahman, Md.M., Ali, P. and Paul, S. (2017) Status and Constrain for Mechanization of Rice Harvesting System in Bangladesh. Agricultural Sciences, 8, 492-506.

https://doi.org/10.4236/as.2017.86037

Received: April 16, 2017

Accepted: June 26, 2017

Published: June 29, 2017

Copyright $\odot 2017$ by authors and Scientific Research Publishing Inc. This work is licensed under the Creative Commons Attribution International License (CC BY 4.0).

http://creativecommons.org/licenses/by/4.0/

\begin{abstract}
To know the position, problems and suggestion of harvest mechanization of rice, the study conducted in 21 upzillas under seven regions (Dhaka, Mymensingh, Sylhet, Comilla, Bogra, Rajshahi and Rangpur) based on different agro-climatic condition and cropping intensity and 126 farmers participated in the interview. For collecting data, a structured questionnaire was used and statistical analysis of the collected data was carried out. In study area, the average cultivable area was 225 to 1239 decimal $\left(1\right.$ decimal $\left.=40 \mathrm{~m}^{2}\right)$ and $97.60 \%$ farmer reaping by sickle and only $0.80 \%$ used combine harvester. Cut paddy transported by head (13.49\%), shoulders $(12.7 \%)$ or both of them of $11.11 \%$ farmer and $44.44 \%$ of farmers used small truck or field threshed. Threshing was mainly done using (49.21\%) closed drum thresher and open drum thresher $(26.20 \%)$, likewise 1 of 126 farmer use head-feed combine harvester. The study area, most farmers $(37.3 \%)$ used kula for the cleaning of rice, but only $8.74 \%$ of farmers used winnower. In considerable amount, $80.95 \%$ of farmers had machinery, while the remaining (19.05\%) did not have machines. Farmers agreed that harvesting was a labor-intensive method (35.71\%) and time consuming $(28.57 \%)$. Transporting of harvested paddy was dangerous and painful for head, shoulder, hand, waist, backbone, leg, etc. With mechanization and the introduction of machinery, $40.48 \%$ of farmers identified the main ceiling as the price of the machine and information/lack of credit system (21.43\%). In survey area, most farmers (36.51\%) identified the vital advantage of mechanized harvesting as lower labor requirement, while $21.43 \%$ of farmers said that a lower loss of rice. All farmers who participated in the interview expressed their need for machinery and mentioned agricultural credit with easy terms and conditions, subsidy for buying machinery and the ensuring of a fair market price for their rice.
\end{abstract}

\section{Keywords}

Crop, Harvesting, Mechanization 


\section{Introduction}

\subsection{Current Status for Agriculture in Bangladesh}

Rice in Bangladesh is an important cereal crop for national food security, and accounts for 93 percent of all food produced, $70 \%$ of average calorie intake and $35 \%$ of household expenditure [1]. Rice production in Bangladesh for FY 2011/12 was 33.88 million MT [2]. There are three rice growing seasons, which are called Boro, Aus and Aman. Of these, the two dominant seasons are Boro and Aman. Boro rice is grown completely under the irrigated ecosystem during the dry period (November to July) while Aman (July to December), Aus (April to August) and Upland rice (March to July) is grown under the rainfed ecosystem. Boro covers the largest land area, followed by Aman and Aus. During 1985, the postharvest loss of rice in Bangladesh was estimated as $13.84 \%$ when mechanical intervention in some of the activities, particularly tilling, spraying, and threshing, was absent. The manual rice harvesting (cutting to winnowing) caused an average loss of about 4.44\% [3]. After 1998, the wide scale adoption of power tillers for tilling led tremendous changes in the crop production sector in Bangladesh.

The most common harvesting system was to cut crops using sickle, and make a bundle with rope and then carry the bundle by balancing it on one's head, although some farmers use bamboo/wooden stick to carry the bundle upon their shoulders. In wet season (Aman) most of the farmers' dried paddy in the field (Figure 1) and carried them to the threshing yard. Some farmers threshed their paddy in the field or road side. In some areas, farmer used paddle threshers,

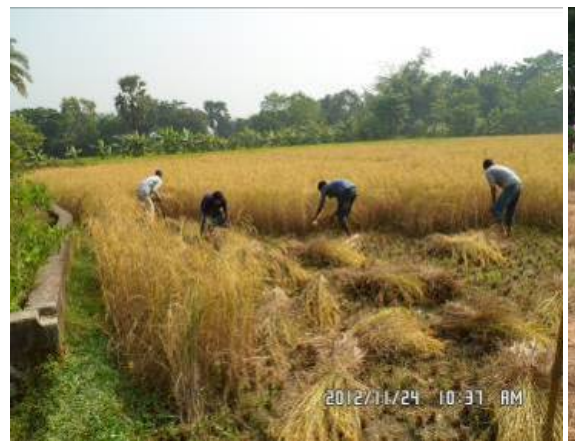

Cutting by sickle

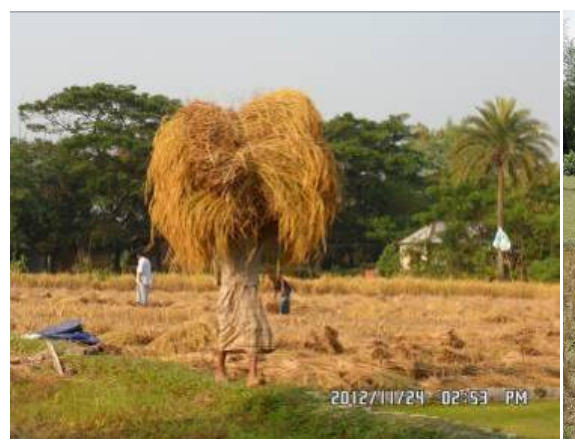

Head carry

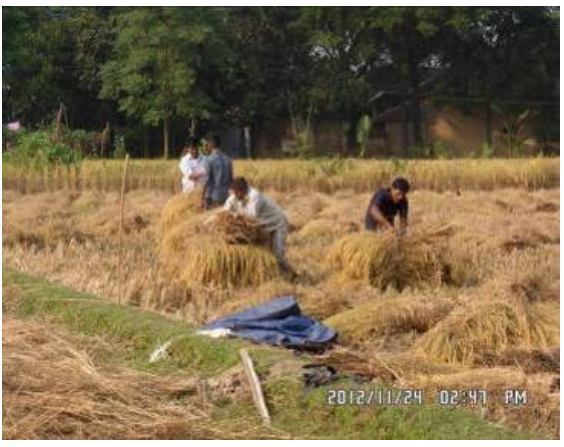

Making bundles with rope

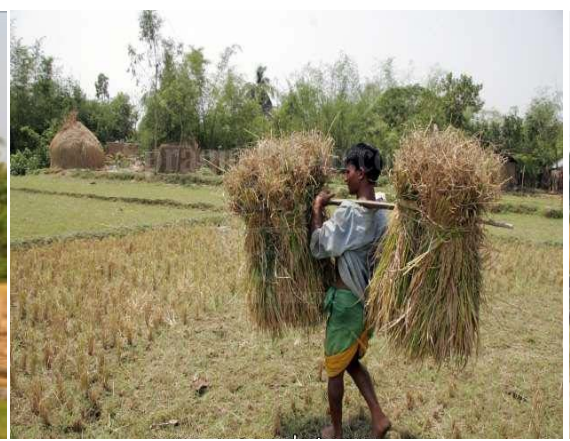

Shoulder carry

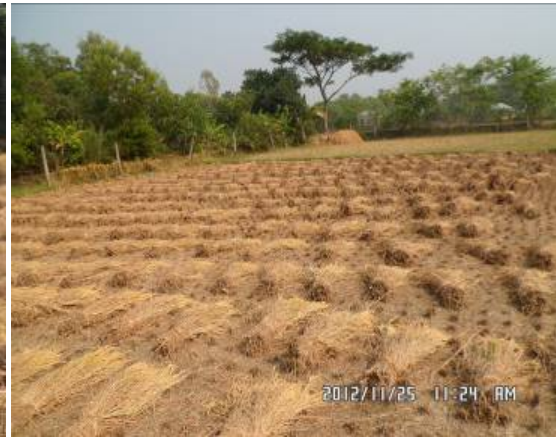

Dry season (Aman harvest)

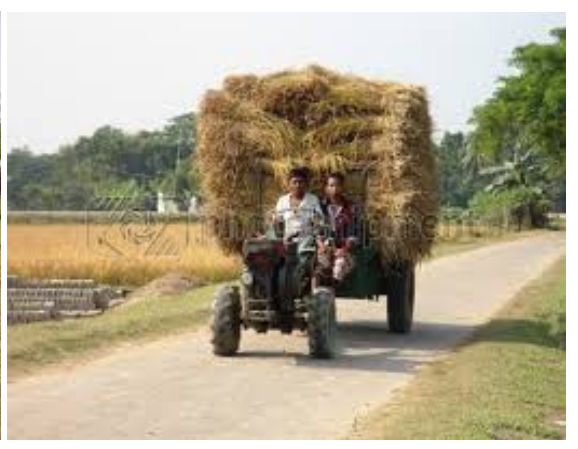

Power tiller operated trolley

Figure 1. Harvesting, bundling, field drying and transporting system. 
open drum threshers (ODT) or close drum threshers (CDT) for threshing the paddy (Figure 2). Farmers in Bangladesh winnowed the harvested crops using kula, and this activity was mostly done by women. However, some progressive farmers used mechanical winnower for cleaning the paddy (Figure 3 ).

In the contemporary context, the mechanization of harvest and post harvest work has become very important in Bangladesh because of the high rate of labor movement from rural to urban and industrial zones due to changes in the economy. Various research institutes (BRRI, BARI) and government institutes (BADC, DAE) have been working with the dissemination of modern harvesting machinery (hand reaper, power tiller operated reaper, self-propelled reaper and head feed combine harvester) and providing subsidy in the range of $25 \%$ to $60 \%$ of the original product price to the farmers (Figure 4).

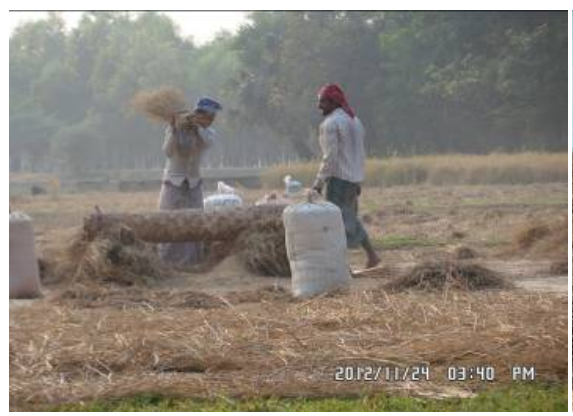

Threshing in field

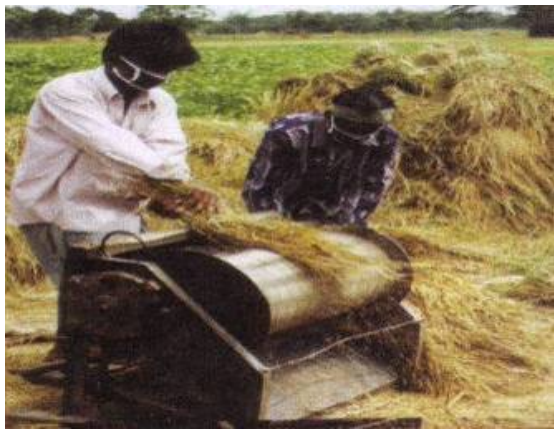

Paddle thresher

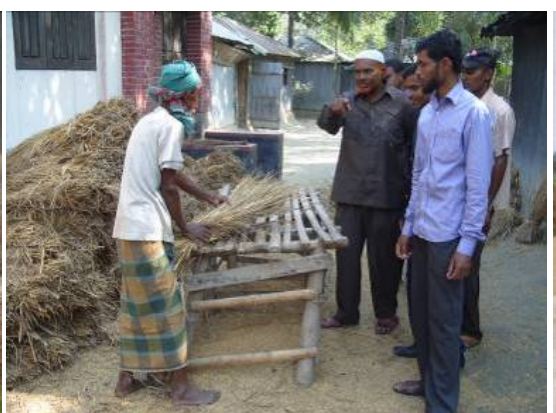

Threshing at the road side

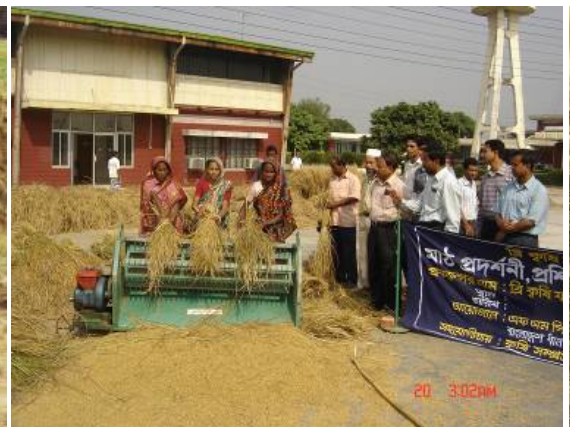

Open drum thresher (ODT)

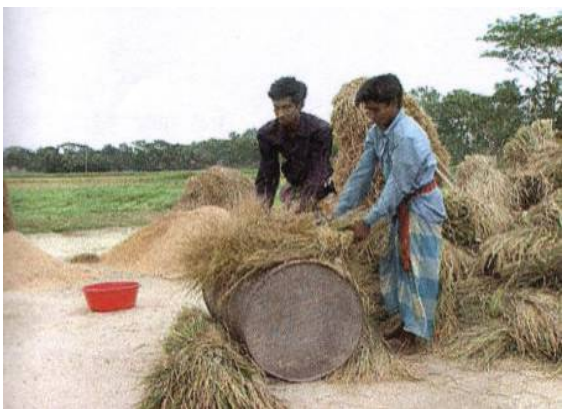

Threshing by drum betting

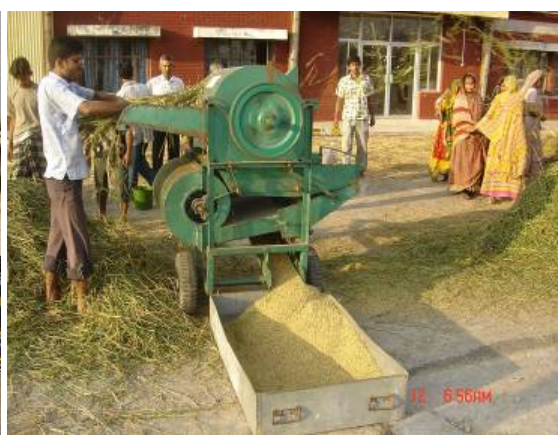

Close drum thresher (CDT)

Figure 2. Threshing practices and tools.

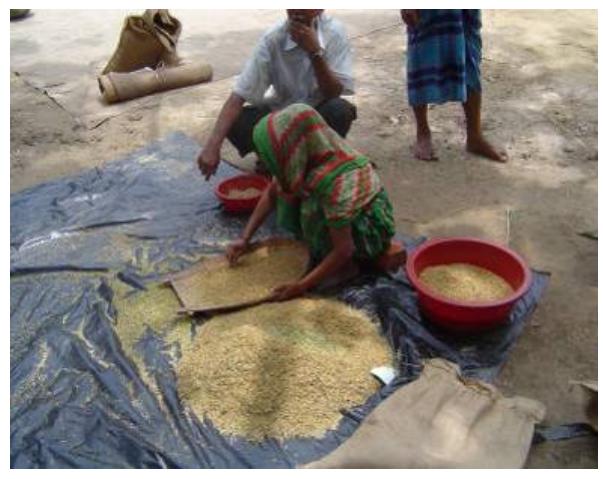

Kula (Common cleaning practice)

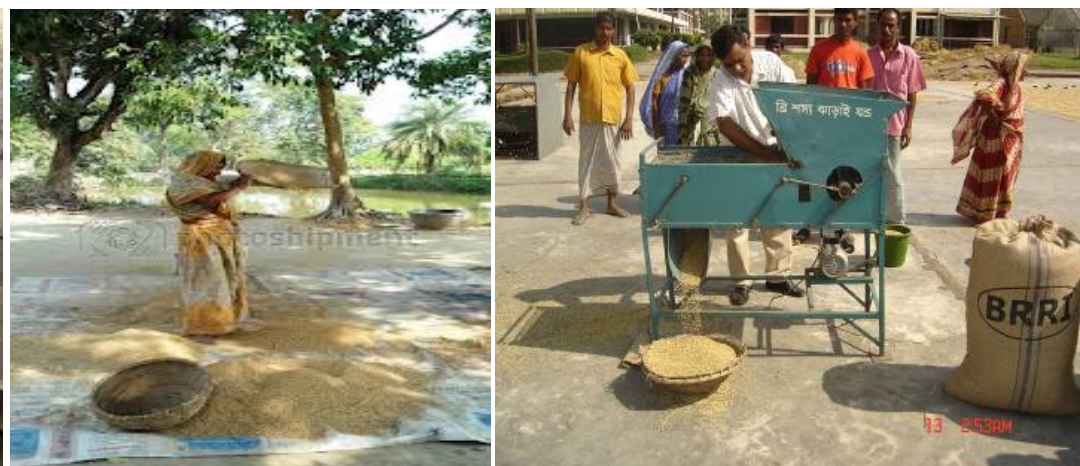

Winnower

Figure 3. Cleaning practices and tools. 


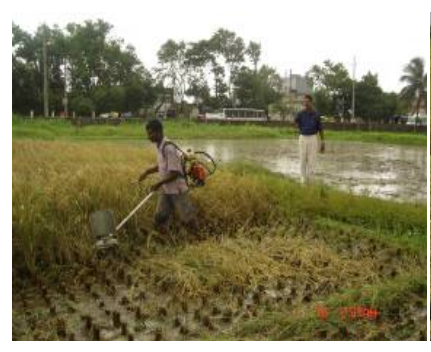

Hand reaper

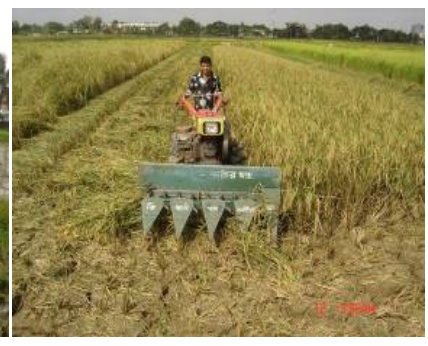

Power tiller operated reaper

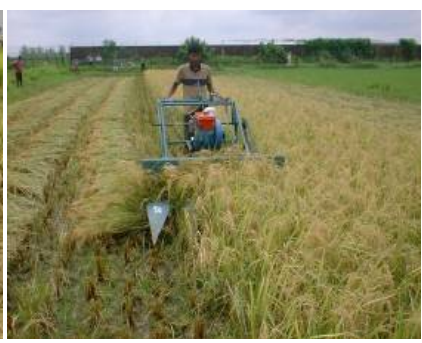

Self propelled reaper

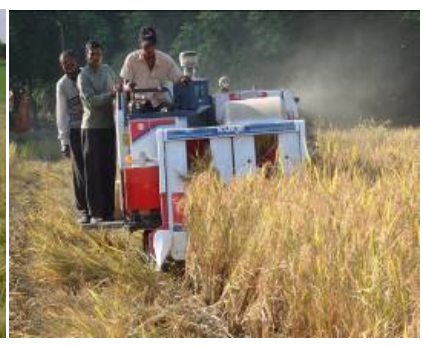

Head feed combine harvester

Figure 4. Modern harvesting machinery.

\subsection{Machinery Use Status}

The serious scarcity of draft power necessitates the use of mechanical power for agricultural production activities. Labor shortage during peak harvesting period compelled the farmers to switch from traditional to mechanized cultivation. The government has, therefore, attached special importance to agricultural mechanization. To encourage the use of machines in agriculture, testing and standardization restrictions have already been withdrawn in the free market distribution system. As a result, the use of agricultural machinery has increased significantly and immense potential is created for further increase. More than 400,000 power tillers are present in the country [4]. In the year 2007, alone 62,000 power tillers have been imported and the number of 4 -wheel tractor has been reported to 12,000 and it was found 5530 in 2002. Currently 2500 to 3000 tractors per year are being imported and used for agricultural purpose, mainly for tillage and transportation [5]. Currently manually operated grain threshers (numbering over 200,000), including close-drum thresher (safe for eyes), along with a power operated ones (estimated number: 12,000 - 15,000) are also in widespread use. These are all made in Bangladesh by local manufacturers using some imported raw materials. The low cost manual machines (Tk 1200 to 2500 each) are generally owned by individual farmers but the power driven ones (costing Tk 15,000 to 25,000 ) are usually hired [6]. The current statistics of farm machinery in Bangladesh is presented in Table 1.

Currently, 150 rice reapers and 100 combined harvesters are being used in Bangladesh. The mechanization of rice harvesting has only reached $15 \%$ of the rice planting area. The use of mechanical harvesters in rice production can avoid losses of about $3 \%$ per season [8]. To establish strategies for the successful mechanization of rice harvesting, it is necessary to assess the factors affecting the mechanization of these activities. Therefore, this study was undertaken with to understand the current status, problems, prospects and probable solutions for the harvesting system and also suggestion improvements to the harvesting system.

Now, the mechanization trend is increasing (Table 2) and day by day, users attitude change, so that the area coverage occupied by machinery.

\section{Materials and Methods}

The study was done under the Korean International cooperation Agency (KOICA)- 
Bangladesh collaborative project titled "Development of Research Capacity of Bangladesh Rice Research Institute" and with the help of Department of Agricultural Extension (DAE).

\subsection{Study Locations}

The study was conducted in 21 villages in seven regions based on different agroclimatic condition and cropping intensity. Dhaka, Mymensingh, Sylhet, Comilla, Bogra, Rajshahi and Rangpur regions were selected based on production

Table 1. Current statistics on farm machinery available in Bangladesh.

\begin{tabular}{ccc}
\hline Sl. No. & Farm Machinery & Number of Units \\
\hline 1 & Power tiller & About 350,000 \\
2 & Tractor & $>25,000$ \\
3 & High speed rotary tiller & 30 \\
4 & Weeder & $>200,000$ \\
5 & Seed-cum-fertilizer distributor & About 60 \\
6 & Sprayer & $1,250,000$ \\
7 & Combine harvester & About 30 \\
8 & Reaper & About 40 \\
9 & Open drum thresher & 150,000 \\
10 & Closed drum thresher & About 35,000 \\
11 & Winnower & About 500 \\
12 & Dryer & About 500 (including rice mill dryer) \\
13 & Hand maize sheller & 12,000 \\
14 & Power maize sheller & 2000 \\
\hline
\end{tabular}

Source of data: [7].

Table 2. Area coverage through farm machinery for rice production.

\begin{tabular}{ccc}
\hline S1 No. & Operation & Area Coverage \\
\hline 1 & Tillage & $70 \%$ power tiller, $28 \%$ tractor, $2 \%$ bullock \\
2 & Transplanting & $98 \%$ manual \\
3 & Weeding & $95 \%$ manual (by hand or manual weeder) \\
4 & Spraying & $>90 \%$ knapsack sprayer \\
5 & Irrigation & $>90 \%$ STW or DTW or LLP \\
6 & Harvesting & $97 \%$ manual (sickle) \\
7 & Threshing & $80 \%$ thresher \\
8 & Winnowing & Farmer's level-100\% sun drying \\
9 & Drying & Village: level Engleberg huller-100\% \\
10 & Milling & Commercial level Engleberg huller-30\%, Rubber roll huller-70\%
\end{tabular}

Source: [9]. 
volume, weather conditions, accessibility, cropping patterns and production surplus. At least one village from each upzilla was selected after considering the intensity of rice cultivation. The sample households were randomly selected using a random sampling technique with arbitrary allocation (Table 3 ) and minimum 3 farmers from each place were selected randomly. The total number of respondents was 126.

\subsection{Questionnaire Preparation}

Farmers'/machinery users opinion was needed to establish the mechanization guidelines, as well as details on their wishes and needs. Structured questionnaire was used to collect the necessary information by interviewing the farmers. A draft survey questionnaire was prepared and pretested to refine the questionnaire.

Table 3. Study locations.

\begin{tabular}{|c|c|c|c|c|}
\hline Region & District & Upazila & Union/Village & No. of Respondent \\
\hline \multirow{3}{*}{ Mymensingh } & Mymensingh & Sadar North & Shambogonj & 3 \\
\hline & \multirow{2}{*}{ Netrokona } & Barhatta & Chandrapur & 3 \\
\hline & & Netrokona Sadar & Shamgonj & 3 \\
\hline \multirow{3}{*}{ Dhaka } & \multirow{2}{*}{ Gazipur } & Joydebpur & Harinal & 3 \\
\hline & & Joydebpur & Tarat Para & 3 \\
\hline & \multirow{3}{*}{ Comilla } & Debirder & Kentment & 3 \\
\hline \multirow{4}{*}{ Comilla } & & Burichang & Rampur & 3 \\
\hline & & Comilla Sadar & Champak Nagar & 3 \\
\hline & \multirow{2}{*}{ Chandpur } & Hazigonj & Balakhal & 3 \\
\hline & & Kachua & Hosenpur & 3 \\
\hline \multirow{3}{*}{ Sylhet } & \multirow{2}{*}{ Habigonj } & Habigonj & Duliakhal & 6 \\
\hline & & Madhabpur & North Surma & 6 \\
\hline & Sunamgonj & Sunamgonj Sadar & Bajra & 6 \\
\hline \multirow{4}{*}{ Bogra } & \multirow{2}{*}{ Bogra } & Bogra Sadar & Telihara & 6 \\
\hline & & Gabtoli & Darial bazaar/Vuligari & 6 \\
\hline & \multirow{2}{*}{ Joypurhat } & Joypurhat Sadar & Bakila, Bakila & 6 \\
\hline & & Panchbibi & Naoda, Naoda & 6 \\
\hline \multirow{3}{*}{ Rajshahi } & Rajshahi & Bagha & Arani, Shahapur & 6 \\
\hline & Natore & Natore Sadar & Mazdighe & 6 \\
\hline & Kustia & Mirpur & Fulbaria & 6 \\
\hline \multirow{7}{*}{ Rangpur } & \multirow{2}{*}{ Rangpur } & Mithapukur & Pira bandh/Jaforpur & 6 \\
\hline & & Pirganj & Fotapur/Tularampur & 6 \\
\hline & \multirow{2}{*}{ Dinajpur } & Khansama & Satiangor/Vadusa & 6 \\
\hline & & Sadar & Mohanpur & 6 \\
\hline & \multirow{3}{*}{ Thakurgoan } & Sadar & Kohor Para & 6 \\
\hline & & Pirgoanj & Joykun & 6 \\
\hline & & Total & & 126 \\
\hline
\end{tabular}


A pre-tested questionnaire was supplied to farmers to get feedback on the harvesting, threshing, cleaning system and operation-related machinery and the associated problems. Survey questionnaires were finalized after incorporating the feedback of the farmers. In the questionnaires, farmers provided relevant information on the harvesting systems what they are practicing for cutting, transporting, threshing, and cleaning.

\subsection{Sample Size}

The sample size of the interview was meaningful; but the present study sample was not reasonable and total respondent was 126 . This interview focused on understanding the present condition and the tendency of farmers' prospects and needs in terms of harvesting machinery in order to formulate a strategy for mechanized harvesting. Machinery operation, advantages and disadvantages related to the harvesting system were considered. Farmers' opinion and desire regarding machinery for harvesting were also considered. To understand the drawback for the introduction of machinery, the most important points regarding mechanization were presented to the farmers and their comments were collected. A statistical analysis of the collected data was carried out and presented in this paper.

\section{Results and Discussion}

\subsection{Machinery Use Status}

\subsubsection{Farm Size}

In the survey area, the average farm size (cultivation area) was 225 to 1239 decimal (1 decimal $=40 \mathrm{~m}^{2}$ ), and maximum ownership was 2400 decimal while minimum ownership was 50 decimal (Table 4). Farm size is a key factor for introducing mechanized harvesting to allow machinery to enter, leave, and turn.

\subsubsection{Harvesting}

All the farmers harvested the crop manually using sickle, which indicated that mechanization in reaping was not yet started in the surveyed area (Figure 5).

\subsubsection{Transportation System}

The carrying of harvested paddy is painful work. Of the 126 farmers surveyed,

Table 4. Average cultivable farm size in surveyed area.

\begin{tabular}{cccc}
\hline \multirow{2}{*}{ Region } & \multicolumn{3}{c}{ Farm size (decimal) } \\
\cline { 2 - 4 } & Minimum & Maximum & Average \\
\hline Mymensingh & 70 & 2175 & 1122.5 \\
Dhaka & 50 & 400 & 225 \\
Comilla & 60 & 1000 & 530 \\
Sylhet & 150 & 1500 & 825 \\
Bogra & 400 & 1794 & 1097 \\
Rajshahi & 50 & 1780 & 915 \\
Rangpur & 78 & 2400 & 1239 \\
\hline
\end{tabular}


$13.49 \%$ transported cut paddy by balancing it on their head, and $12.7 \%$ used their shoulders. $11.11 \%$ of farmers carried harvested paddy on both head and shoulders. Only $18.25 \%$ of farmers sometimes used head carry and power tiller operated trolley or manual operated trolley. $44.44 \%$ of farmers reported that they threshed the paddy in the field and used small truck (pickup) for carrying harvested paddy (Figure 6). Most of the farmers' opinion, during the transported harvested paddy they feel pain in head, shoulder and waist.

\subsubsection{Threshing}

Threshing was mainly done using either close drum thresher $(49.20 \%)$ or open drum thresher (26.20\%), as shown in Figure 7, whereas $16.70 \%$ of farmers reported that they used paddle threshers. $7.14 \%$ of farmers reported that they performed threshing by beating, treading or other methods. In the survey area, only $0.97 \%$ farmers' use head-feed combine, but nobody use the whole feed combine harvesters and head feed thresher due to a lack of access.

\subsubsection{Winnowing}

In the survey area, most farmers $(37.3 \%)$ used kula for the cleaning of rice, and followed by $32.54 \%$ of farmers used kula with an electric fan. In the survey area,

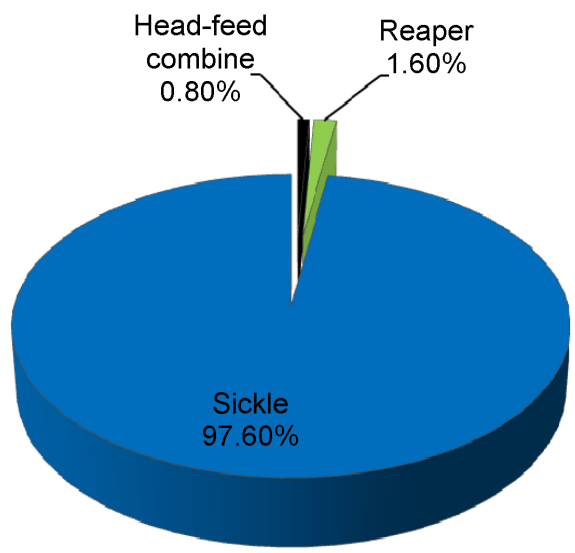

Whole-feed combine: $0.00 \%$

Figure 5 Rice cutting system by farmers.

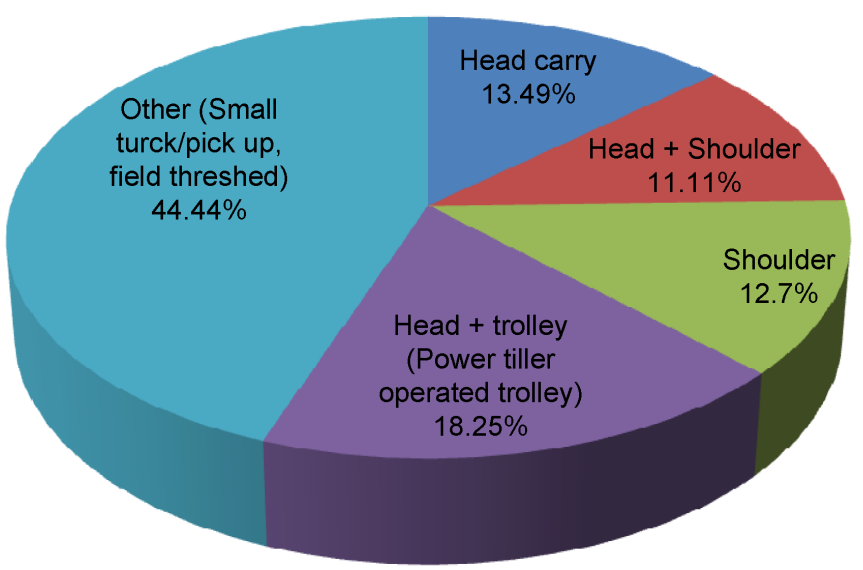

Figure 6 Carrying method of harvested paddy to threshing yard. 
only $8.74 \%$ farmers used a winnower and $3.17 \%$ use other equipment for cleaning rice (Figure 8 ).

\subsubsection{Machinery Use Status}

The overall $80.95 \%$ of farmers had machinery, while the remainder $(19.05 \%)$ did not have machines. Looking at the types of machinery, $50 \%$ of farmers used whole feed thresher (close drum thresher), 26.47\% of farmers used open drum thresher, while $20.59 \%$ used other machinery (paddle thresher). In the project area, only $0.98 \%$ farmers using combine harvesters, $1.96 \%$ uses reapers but none use binders (Figure 9).

\subsection{Problems of Harvesting System}

\subsubsection{Problems in Harvesting}

About $35.71 \%$ of farmers agreed that harvesting by sickle was a labor-intensive method (Figure 10) while $28.57 \%$ of farmers described manual harvesting by sickle as time consuming. Of the respondents, $16.67 \%$ of farmers argued that manual harvesting by sickle affected the quantity of crops due to shattering.

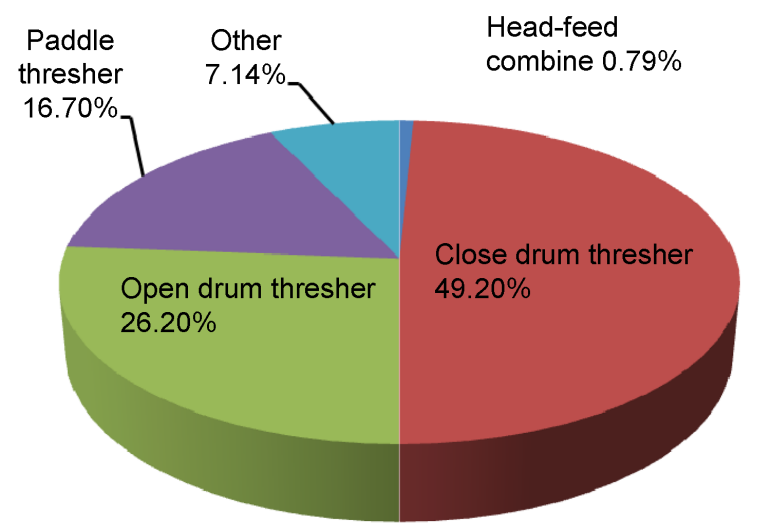

Other: Beating by wooden/bamboople, steel/concrete frum beating

Figure 7 Rate of farmers using machine/tools for threshing of rice.

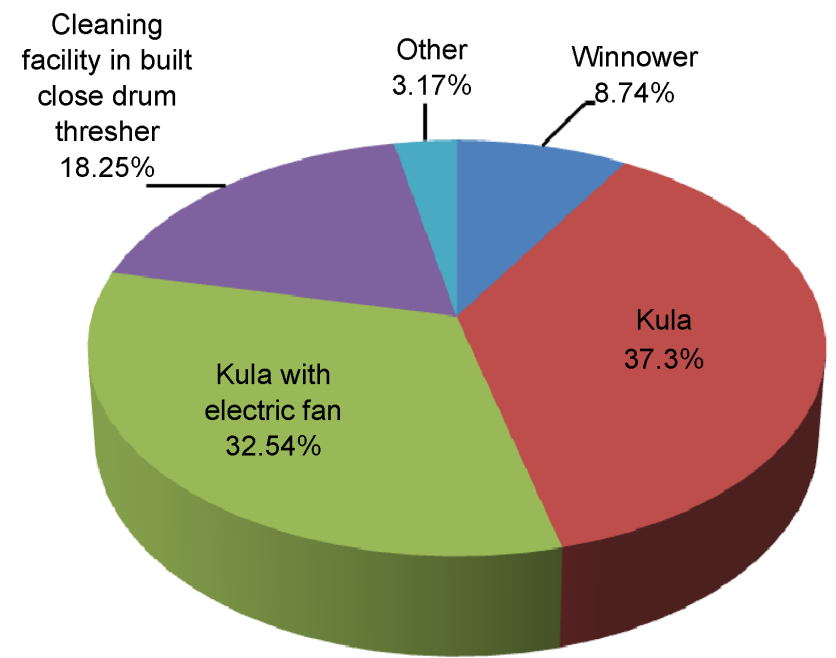

Figure 8 Rate of farmers using different tools for cleaning of rice. 


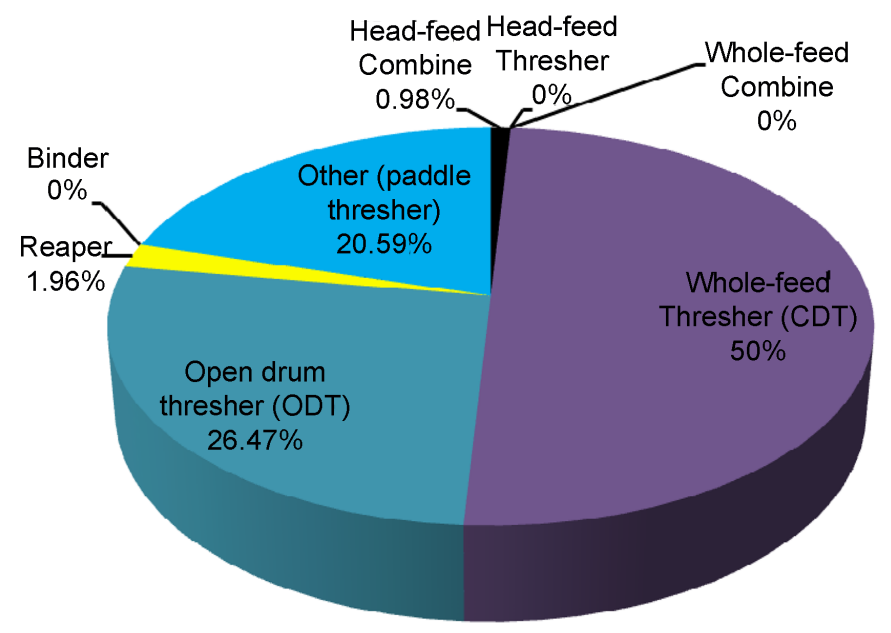

Figure 9 Rate of farmers having harvesting machines.

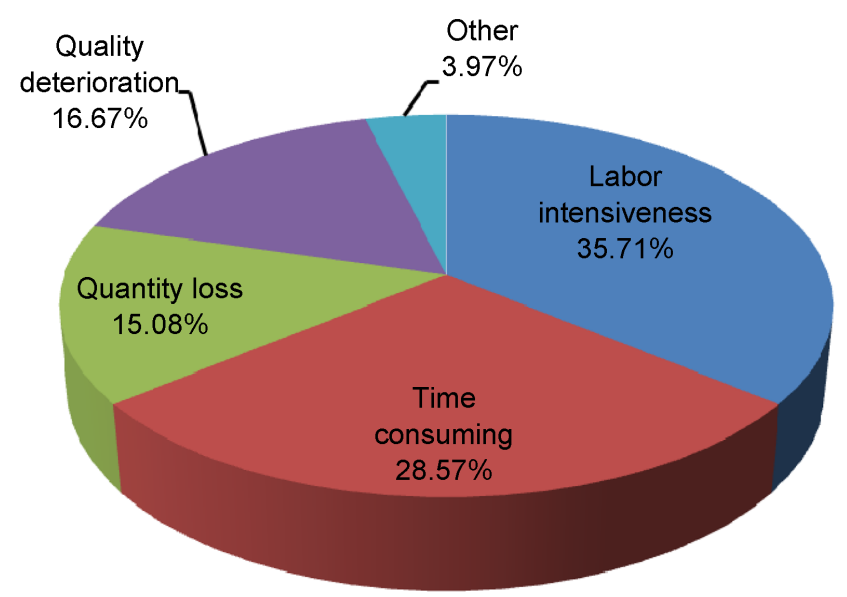

Figure 10. Disadvantages of current cutting method (by sickle) of rice according to farmers' comments.

However, $15.08 \%$ farmers considered that current cutting methods (sickle) resulted in a quality loss and $3.97 \%$ opinion has no alternatives.

\subsubsection{Problems in Carrying}

In the survey area, most of the farmers considered the carrying/transport method to be highly difficult. Transporting of harvested paddy was dangerous and painful for head, shoulder, hand, waist, backbone, leg, etc. The head carry caused pain in the head and neck, while shoulder carry caused pain in shoulder and arms. However, the common carrying system of head and shoulder has serious impacts for human health, even causing death. Farmers argued that they have no alternative way to carry the paddy.

\subsubsection{Problems in Threshing}

$25.40 \%$ of farmers described farming as labor-intensive work, while $34.13 \%$ described it as time-consuming work. $18.25 \%$ of farmers said that the use of open drum thresher and close drum thresher resulted in quantity loss, though $13.49 \%$ of farmers complained that it resulted in quality loss (Figure 11). 


\subsubsection{Problems in Winnowing}

Kula was commonly used for cleaning of paddy/rice, grain, etc. in Bangladesh. Cleaning by kula was labor-intensive and time consuming. The kula was held by hand, and sometimes its operation caused pain in the hands and arms. The dust created during cleaning is also harmful.

\subsection{Investigation for Farmers' Opinion}

\subsubsection{Farmers' wanting about Mechanical Harvesting}

Figure 12 shows the farmers' need and type of machinery use. 63\% farmers want partial mechanization because of worry about un-employment; moreover rest (37\%) of them essential full mechanized rice harvesting. The result indicated that $23.81 \%$ of farmers want to use reaper and thresher, while $14.29 \%$ of farmers are interested in head feed combine harvesters. $23.02 \%$ of farmers wanted a thresher and $5.56 \%$ of farmers desired a reaper. Only $0.79 \%$ farmers were interested in whole-feed combine, because its size made it impractical for their small fields, in contrary $26.19 \%$ farmers need winnower for cleaning rice after threshing.

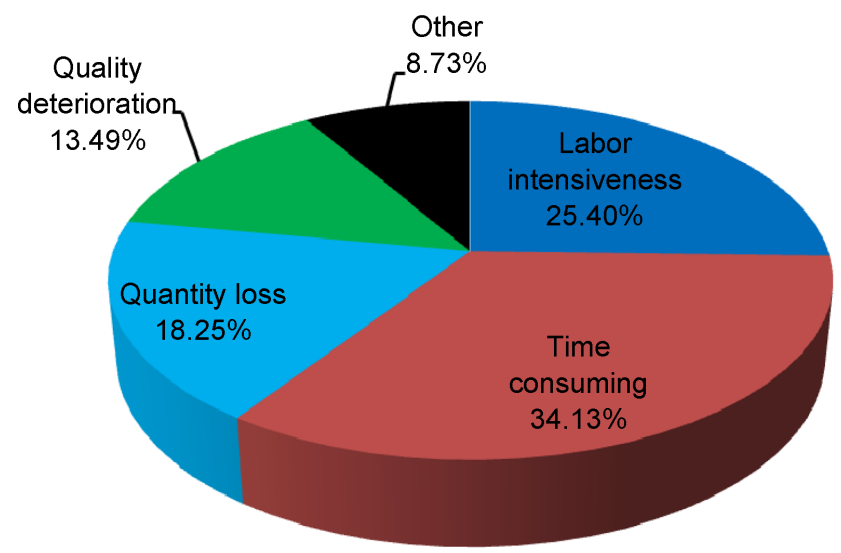

Figure 11. Disadvantages of current threshing method of rice according to farmers' comments.

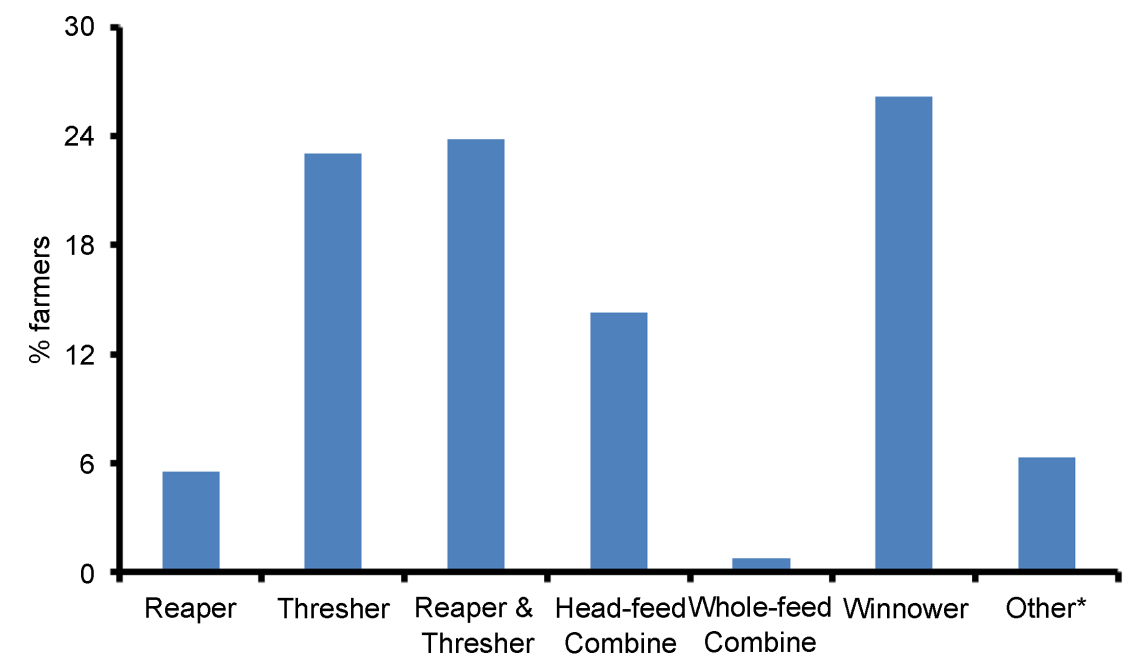

Figure 12. Rates of farmers need to use machines for mechanization of rice harvesting system. 


\subsubsection{Constraints of Harvest Mechanization}

In mechanization and the introduction of machinery, $40.48 \%$ of farmers identified the main restriction as the price of the machine and $21.43 \%$ mention the information/awareness about machine, lack of credit (complicity) and government initiative is the main problem of harvest mechanization. Other minor restrictions identified were poor farm roads (6.35\%) and small size of fields (5.56\%) (Table 5).

\subsubsection{Farmers' Opinions about Mechanized Harvesting}

Table 6 shows that most farmers (36.51\%) identified the vital advantage of mechanized harvesting as a lower labor requirement, while $21.43 \%$ of farmers said that lower loss of rice was another incentive for harvesting mechanization. Only $15.87 \%$ of farmers identified low cost of harvesting as the main purpose of harvest mechanization, moreover $14.29 \%$ farmers seems that harvesting machinery use increase the social status and better livelihood.

\subsubsection{Suggestions for Improved Mechanized Harvesting}

Farmers expressed the opinion that they would benefit in different ways by introducing the harvesting machinery, as they would get extra time for doing off-farm work during the lean period as rice harvesting starts, neighboring farmers could borrow the machinery, and the new generation would show a greater interest in modern agriculture. It would also create an employment opportunity. Poor and marginal farmers who did not have the ability to purchase machinery could borrow to meet the requirements.

In this interview, the similar needs of the farmers were disclosed in broad outlines. All farmers who participated in the interview expressed their need for

Table 5. Factors affecting the use of machine(s) for rice harvesting from farmers (\%).

\begin{tabular}{cccc}
\hline Disadvantages/Factor & Farmer (\%) & Rank & Remarks \\
\hline Price of machine & 40.48 & 1 & \\
Information/awareness about machine & 21.43 & 2 & \\
Lack of credit system and government initiative & 21.43 & 2 & Others: rental hire \\
Poor farm road conditions & 6.35 & 3 & fervice, group of \\
Small size of fields & 5.56 & 4 & \\
Other & 4.76 & 5 & \\
Total & 100 & & \\
\hline
\end{tabular}

Table 6. Advantages of harvest mechanization from farmers (\%).

\begin{tabular}{cccc}
\hline Parameter & Ratio (\%) & Rank & Remarks \\
\hline Lower loss of rice & 21.43 & 2 & \\
Lower labor requirement & 36.51 & 1 & \\
Lower cost in harvest & 15.87 & 3 & Others: better livelihood, social status \\
Save quality & 11.90 & 5 & \\
Other & 14.29 & 4 & \\
Total & 100 & & \\
\hline
\end{tabular}


machinery such as USG applicator, transplanter, harvester and weeder to increase crop productivity and cropping intensity. The main problems identified in buying and using such machinery was high price and small scale of land. As suggestions to resolve the various constraints hindering the rice productivity, all participant farmers mentioned agricultural credit with easy terms and conditions, subsidy for buying machinery and the ensuring of a fair market price for their rice.

The participants urged the government to take effective initiatives via the local government or extension department to help the actual rice farmers to achieve greater rice productivity by using machinery. Finally, the participants mentioned that sustainable and field oriented suitable rice production technology needed to be introduced.

\subsubsection{Suggestion for Mechanized Harvesting Policy}

The following suggestions are made on mechanized harvesting policy based on field information.

$>$ Farmers want have capital intensive machine on subsidized price and an easy credit facility.

Extensive field demonstrations are needed for harvesting machinery. Meetings, farmers' workshops, training, field days and demonstrations can promote farmers knowledge on the benefit of using the machine, and learn how to operate and maintain it.

The establishment of farmer groups for harvesting service is also important. As larger rice fields can be more productive, it is necessary to form cooperatives and merge small farms together.

Development of entrepreneurship is urgently needed for providing custom hire service to the farmers.

Research institute and extension agents can play vital role by providing demonstration and training on the operation and maintenance of the modern machine which ultimately enhance the farm productivity.

So, there is a broader avenue to introduce small to large machinery for enhancing the farm income in the study area. The key strategy in harvesting mechanization is to use machinery in every stage. The suggested ultimate destination of harvesting machinery is the combine harvester, as shown in Figure 13.

\section{Conclusions}

In the surveyed area, every farmer harvested crops manually using a sickle. Modern harvesting machines such as reapers and combine harvesters were negligible amount in the farmers' fields. Farmers were not so much familiar with the performance of combine harvester, or even with the reaper. Farmers described harvesting as labor-intensive and time-consuming work. Farmers used open drum thresher, close drum thresher and paddle thresher for threshing the paddy, either in the field or in the home yard. Mechanical winnowing units and traditional equipment kula were found in the surveyed area for cleaning the crop. 


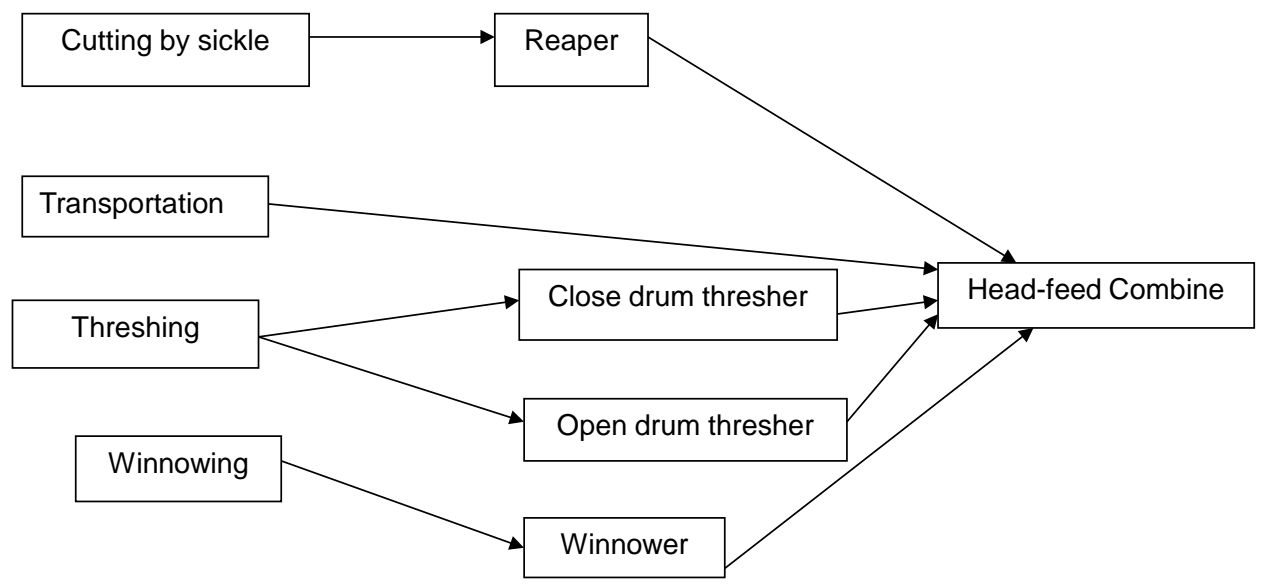

Figure 13. Diagram for suggested harvest mechanization.

Modern farm machinery need assessment was done in the surveyed area. Every farmer wanted modern harvesting machinery (reaper, thresher and combine harvester), but in initial investment was very high which was beyond the purchasing capacity of the farmers. Moreover, they wanted to buy the machinery for a subsidized price. The government should take an initiative to distribute such type of capital intensive machines on a subsidized basis. Demonstration and mass media publication is necessary to create faster awareness of harvesting technology. The important factors affecting farmers' use of rice harvesting machinery include farmer education, training, knowledge, perception on machinery and capital.

\section{Conflicts of Interest}

No potential conflict of interest relevant of this article was reported.

\section{Acknowledgements}

The study was carried out with the support of "Development of Research Capacity of Bangladesh Rice Research Institute Project” founded by KOICA and Government of Bangladesh (GoB) and Department of Agricultural Extension (DAE).

\section{References}

[1] Abedin, M.Z., Rahman, M.Z., Mia, M.I.A. and Rahman, K.M.M. (2012) In-store Losses of Rice and Ways of Reducing Such Losses at Farmers' Level: An Assessment in Selected Regions of Bangladesh. Journal of the Bangladesh Agricultural University, 10, 133-144. https://doi.org/10.3329/jbau.v10i1.12105

[2] World Food Programme (2012) Food Security Monitoring Bulletin. www.wfp.org//bangladesh-food-security-monitoring-system

[3] Quasem, M.A., Anwarul Haque, A.K.M., Choudhury, N.H. and Arboleda, J.R. (1985) Rice Post Harvest Practices and Loss Estimates in Bangladesh: Drying to Milling. Field Documentation No. 8, BRRI, Gazipur.

[4] Alam, M.M., Kabir, W. and Khan, I.N. (2008) Booklet on Mechanization-Its Trend and Opportunities in the Agricultural Production System in SAARC Countries. SAARC Agriculture Centre, Bangladesh Agricultural Research Council (BARC), 
Dhaka.

[5] Matin, M.A., Alam, M.M., Khan, E.N., Khan, M.H. and Khan, M.N.I. (2008) Problem and Prospect of Production of Agricultural Machinery in Bogra. A Research Report. Rural Development Academy, Bogra.

[6] Farouk, S.M., Ziauddin, A.T.M. and Ahmmed, S. (2007) Agricultural Mechanization Policies and Strategies for Employment Generation and Poverty Alleviation in the Rural Areas of Bangladesh. Proceedings of the National Workshop on Agricultural Mechanization, Dhaka, 4-5 June 2007, 166-173.

[7] Ahmed, N.U. and Matin, M.A. (2008) Farm Mechanization for Smallholder Agriculture in Bangladesh. Proceedings of the Regional Workshop on Farm Mechanization for Small Holder Agriculture in SAARC Countries, Dhaka, 22-24 September 2008, 106-116.

[8] Wohab, M.A. (2012) Status Agricultural Mechanization in Bangladesh. www.unapcaem.org/Activities\%20Files/A1112Rt/bd.pdf

[9] Bangladesh Rice Research Institute (BRRI) (2010) Farm Level Evaluation of BRRI Developed Machinery. In: The BRRI Annual Research Review 2009-2010, A Report Presented from Farm Machinery and Postharvest Technology Division, Bangladesh Rice Research Institute, Gazipur.

Submit or recommend next manuscript to SCIRP and we will provide best service for you:

Accepting pre-submission inquiries through Email, Facebook, LinkedIn, Twitter, etc. A wide selection of journals (inclusive of 9 subjects, more than 200 journals)

Providing 24-hour high-quality service

User-friendly online submission system

Fair and swift peer-review system

Efficient typesetting and proofreading procedure

Display of the result of downloads and visits, as well as the number of cited articles

Maximum dissemination of your research work

Submit your manuscript at: http://papersubmission.scirp.org/

Or contact as@scirp.org 